Proceedings of Business and Economic Studies

Research Article

\title{
Based on the Current Situation and Thinking of Art Appreciation Education in Colleges and Universities
}

Xin Li

Zibo Vocational Institute, Zibo 255314, Shandong Province, China

Abstract: The development and progress of society put forward higher requirements for the comprehensive quality of contemporary college students. As a public elective course to strengthen quality education and improve students' art accomplishment, art appreciation course has its own discipline characteristics and teaching rules. It enriches students' aesthetic concept and always cultivates their art appreciation ability through aesthetic education of excellent art works and in all over the world. How to face all the students to popularize art knowledge and cultivate their aesthetic ability is a problem that art educators think about. This paper makes an in-depth analysis of their own conditions of non art majors and expounds the coping strategies. It is hoped that it will help to broaden students' art vision, improve their art accomplishment, enhance their humanistic quality and promote their allround development.

Key words: Colleges and universities; Art appreciation; Education and teaching

Publication date: October, 2020

Publication online: 31 October, 2020

*Corresponding author: Xin Li, 16296461@qq.com

\section{Introduction}

Art, also known as plastic art or visual art, as the name implies, is about the art of beauty, which uses some materials to create visual images or devices with specific space and aesthetic value.After years of exploration, it has been confirmed that although the public art appreciation education in Chinese universities has made great progress, the process of public art appreciation is still in the stage of development and improvement.
Art appreciation education is an important content and method of humanistic education. Through the study of art appreciation course, college students can learn knowledge, understand and interact with many excellent art works, realize the fine arts value of Chinese and foreign art works, cultivate aesthetic concepts, improve art taste, and improve the overall quality. This is of great significance to broaden the art vision of college students, cultivate their aesthetic feeling, and enhance their personality and creativity.

\section{The basic characteristics of art appreciation teaching in Colleges and universities}

\subsection{Art education is one of the indispensable parts of the curriculum of College Students' all- round development}

Art education is a process that enables students to appreciate and understand works from all angles to improve their aesthetic ability through appreciation. To reveal the artistic characteristics and cultural significance of fine arts mainly shows the ability to perceive the aesthetics of fine arts from the outside to the inside, and reasonably from the perception through the interpretation and appreciation of specific fine arts.In addition, art appreciation course education in quality education should emphasize "Popularization" and "Aestheticization". Only in this way can colleges and universities take the initiative to carry out new educational reform. Through strengthening college students' appreciation of fine arts, students can establish a sound aesthetic knowledge structure, improve art literacy, and form healthy and noble aesthetic intuition and aesthetic taste in the process of learning and 
appreciating works.

\subsection{Art education has its own disciplinary characteristics}

The education of art appreciation course is different from the internal course of fine arts major. Its emphasis is to cultivate and improve college students' aesthetic ability, imagination and creative thinking ability. In order to teach this course well, teachers' professional quality and teaching ability are required to be high. Teachers with good teaching ability are required to combine these knowledge organically. They also need rich experience in art creation, solid theoretical knowledge of art history, as well as knowledge of literature, history, philosophy and other related disciplines, so that students can understand the essence of art from different angles.

In the teaching process of art appreciation course, teachers usually take painting, sculpture, architecture and arts and crafts with universal art value as educational content and aesthetic appreciation objects. Therefore, before the classroom teaching process, teachers need to determine the teaching objectives, teaching process and teaching methods according to the characteristics of students. In the selection of teaching content, we should pay attention to the selection of the theme and the scope of the current students can accept, and then integrate the unique style of teachers into it, so as to help students appreciate and understand these outstanding art works with relatively complete content and form. In general, teachers are advised to choose contemporary works with universality, Futurism and innovation as much as possible. Only when the students appreciate the works within the current level can they bring strong artistic appeal to contemporary college students, cultivate and shape their aesthetic feeling and improve their overall quality.

\subsection{The subject position of students in art appreciation course teaching is very important}

Teachers should try to let students as the main body to feel art appreciation. Students of art appreciation course come from different majors. Because the knowledge structure of other majors and students of aesthetics is different, different students may have different views, different aesthetic feelings and different aesthetic conclusions when appreciating fine arts. Therefore, teachers need to maintain a positive attitude of guidance and encourage students to actively think deeply and express their aesthetic views boldly. Teachers must analyze and comment on all kinds of aesthetics in time, guide them to combine the rational and perceptual knowledge to appreciate, truly realize the artistic value and humanistic significance of fine arts, and make reasonable evaluation on the works. Only in this way can we stimulate students' aesthetic view and interest in aesthetics.

\section{The role of art appreciation course on Contemporary College Students}

\subsection{Cultivate sentiment}

The appreciation of fine arts is that the aesthetic subject actively reflects the aesthetic object. In this process, the aesthetic subject obtains rich emotional experience. Regular aesthetic activities of college students can cultivate their temperament and purify their thoughts. For example, the image of father by Luo Zhongli, an oil painter, makes people feel the beauty of simplicity, honesty, diligence and kindness of traditional Chinese farmers. Luo Zhongli's simple style of paying attention to nature awakens people's strong interest in ideal life. There are also some works showing patriotism, cooperation, strong will, selfless quality and the warm and cold colors of the world that artists can handle. The power of truth, kindness and beauty can also be felt by students in different paintings. The contents and themes shown in these art images arouse people's love for the ideal and beautiful life. It can help college students to establish accurate and healthy aesthetic concept and attitude towards life.

\subsection{Establish aesthetic concept}

Through the appreciation and study of excellent Chinese and foreign art works, students can gradually understand the deep meaning of the works through the form and image level of the works. With the deepening of art appreciation education, the art form and language of art works become more and more vivid, and the content is more and more rich. When students taste and interpret other works by reflecting the artist's humanistic feelings, the works will show rational content, such as rational content, philosophy, characteristics of the times and national spirit, which will be a refreshing pleasure.At this time, the artist's work is no longer the only state of the soul, but a kind of "intermediary", becoming the "bridge" of emotional communication between artists and students. In this 
way, in the educational activities of appreciation courses, students can fully enjoy the spiritual pleasure brought by fine arts, accumulate specific aesthetic experience, improve aesthetic consciousness, develop aesthetic wisdom, and establish a reasonable aesthetic concept.

\subsection{Cultivate students' imagination and creativity}

Art appreciation refers to the interaction and infiltration of art products, artists' social background and life, viewers' knowledge background, life experience and emotion and emotion. In fact, the process of appreciating fine arts is that students actively create while appreciating. Fine arts can fully mobilize students' potential creativity and imagination. The research shows that the better the students' reaction to the work, the more extensive the students' perception of lines, shapes and colors, and the imagination around the images and emotions of the works.In particular, some works can easily provide students with a wide space for free imagination and creativity, such as abstract painting and abstract sculpture. These transformed and exaggerated abstract works can more fully stimulate students' imagination and creativity.

In addition, the appreciation of fine arts should be carried out through dialogue and communication. It includes the dialogue and exchange between teachers and students, between students and students, and between audience and works. Any dialogue and communication must be realized through language. For students, these types of dialogue and communication are intertwined. On the one hand, the works convey information to students through the elements of shape, composition, color, line, and the content or plot of the description, and the students constantly obtain these information and make emotional reactions by relying on their keen intuition and aesthetic feelings. On the one hand, students express their understanding and feelings of fine arts by talking and discussing with teachers and colleagues and listening to the feelings of others. In the process of dialogue and communication, students constantly enrich their inner feelings. Through these expressions from the heart, students' language ability can also get rapid development.

\section{Problems in art appreciation teaching in Colleges and Universities}

Although art appreciation education has become an important part of the public moral education system in universities, there are still some problems to be solved in some teaching activities.

\subsection{The teaching method fails to combine with the actual situation of students}

First of all, it does not get high attention and status in today's education chain. At present, in the art appreciation of colleges and universities, the teaching method is too traditional, which leads to the dull teaching content and neglects the cultivation of students' humanistic quality. Art appreciation education in some schools is mainly carried out through two courses: Art appreciation and calligraphy appreciation are lack of diversity in educational objectives, contents and plans or long-term curriculum planning.

\subsection{Lack of overall image and consciousness}

At present, the development of aesthetic education in Colleges and universities is far less than that of moral education, intelligence education and sports popularization, and there is no in-depth and complete construction of effective education management system and supervision system. Similarly, both teachers and students pay little attention to art appreciation education. Thus indirectly promoted the students' learning attitude in the art appreciation class is not correct, and the teacher's traditional negative teaching method also affected the students' interest in the course.

\subsection{The shortage of professional teachers has affected the teaching quality}

The teaching staff of art appreciation course is very weak, and the quality of textbook selection and purchase is uneven. And art teachers in teaching methods and the use of media technology and the understanding of students' aesthetic needs are different, so it is difficult to fully meet the interests of students. As students can not receive positive feedback in class, some students gradually lose interest in learning and affect the quality of education.

Therefore, how to provide students with a good art appreciation course, how to innovate on the existing basis, and how to scientifically establish a public art appreciation course model for ordinary universities have become an important topic for art teachers. Teachers need to continue to explore the best way of teaching according to the situation of students in teaching.

\section{Development Countermeasures of art appreciation teaching in Colleges and}




\section{Universities}

\subsection{Combining life reality in Teaching}

According to the principle that art originates from life, teachers should guide non art students to acquire learning motivation in art appreciation class. The most basic way for teachers to provide good art appreciation courses for non art students is to try to reduce the frequency of using professional terms. Let students understand and apply it to art appreciation. Students can be inspired to appreciate from the perspective of art from the things they often see in life. For example, for real money, students can be asked to discuss quality, color, brightness, and texture.On this basis, it arouses students' interest and gradually deepens. First, it discusses the banknotes and silver coins in circulation before China, then discusses the ancient coins in circulation, and finally introduces the theme, how to appreciate the coins and their artistic value in Song Dynasty. This kind of open education starts from the objects closely related to life, and naturally guides students to enjoy the contents of the classroom. It can not only achieve the purpose of art appreciation class, but also help students form a good habit of observing and thinking about life.Art is higher than life, but art comes from life.

\subsection{Correctly understand the publicity of art appreciation teaching}

Different from other art education, art appreciation education has the characteristics of publicizing art.Some students emphasize skills and ignore fine arts, which leads to their failure to see the progress of humanities. This will have a negative impact on the art appreciation and the quality of education. College art education includes professional art education and public art education. The main purpose of the former is to cultivate professional art talents, while the latter is to improve the aesthetic education of students' humanistic quality.

\subsection{Diversification of teaching and evaluation methods}

In Teachers' curriculum, teachers must learn how to use teaching time scientifically and effectively to improve teaching efficiency. According to the teaching content, it is necessary to integrate teaching materials, innovate teaching methods, enrich teaching contents, stimulate students' interest in learning, and try to combine with students' major. Teachers should also use flexible methods such as voting assessment, grade assessment and comparative assessment to evaluate students' work. In this way, students can be more clearly aware of the advantages and disadvantages of their own learning, and provide the direction of improvement and improvement.

\subsection{Improving teachers}

Comprehensive and high-quality art appreciation teachers play an important role in improving the quality of art appreciation education in universities. At present, art appreciation courses in some schools are part-time by professional teachers of fine arts colleges. Although these teachers have strong teaching ability, they can not meet the needs of ordinary students to improve their aesthetic quality and art appreciation ability. In order to solve this problem, universities should strengthen the training of art teachers. The importance of art appreciation education and teaching activities in universities should be reflected in strengthening the professional quality of excellent art teachers, and enhancing the strength of art teachers by improving their professional knowledge level, professional level, teaching ability and expression.

\subsection{Enrich the teaching content}

The teaching methods of art appreciation course are different, and the teaching effect is also different. In recent years, art appreciation courses in Chinese universities are generally set in a certain social background, content and characteristics. Some training exercises focus on the first two aspects. Students often hear how the teacher explains the background of the artwork, the resume of the author and so on. The content of the plot copied in the work, the artistic conception of the artist, the composition, color, space treatment, style characteristics and other form elements of the work itself. In order to encourage students to attend class, some teachers often look for ways to help them appreciate art. The interesting content that has nothing to do with art appreciation turns art appreciation class into story lesson and moral education course. Therefore, art appreciation education stays on the surface and can not really enter into aesthetic activities.

\subsection{Carry out practical activities}

The appreciation of art originates from life. Therefore, teachers must combine theory with practice, and carry out vivid and interesting educational practice through more direct materials. For example, teachers should encourage students to enter the society to look for buildings or scenes with art elements, and through their 
holiday work, find moments with art value, and help students feel the status and role of art in life.

\section{Conclusion}

As an important means of quality education, public art appreciation course in Colleges and universities integrates humanistic culture with scientific culture, criticism and creation. Art appreciation course has the task of improving students' humanistic quality, developing students' art achievement and aesthetic ability. The nature of art theme itself determines that art appreciation is an infinite process of recreation. There is no fixed method or unified art appreciation standard; This needs to actively explore, innovate and change, improve the classroom efficiency in teaching practice, and show the charm and value of the original art. Art appreciation can cultivate college students' imagination, creativity and language expression ability, enrich their aesthetic taste, optimize their emotional structure, and enhance their aesthetic ability. Humanistic quality promotes the all-round development of students. In short, art appreciation education can help improve the overall quality of college students.

\section{Reference:}

[1] Xiang X. Analysis of the application of art appreciation in art teaching in Colleges and universities [J]. Beauty and the times (middle), 2020(4): 103-104.

[2] Li AM. Analysis of humanistic spirit cultivation in art appreciation general course teaching in Colleges and universities [J]. Journal of Guangxi Normal University of science and technology, 2019, 34(2): 120-122+126.

[3] Liu J. The current situation and Countermeasures of "art appreciation" course teaching in Colleges and universities [J]. New Curriculum Research (xunjian), 2018(9): 23-24 + 36.

[4] Zhao LJ. Preliminary study on teaching method reform of Chinese folk art appreciation course in Colleges and universities[J]. Popular literature and art, 2018(8): 201-202.

[5] Wang XB. The importance of art appreciation course in quality education in Colleges and universities [J]. Art education research, 2017(20): 110.

[6] Gao CQ. Role of Art Appreciation in Art Teaching in Colleges and Universities[J]. Research on Art Education, 2017(14): 92. 